\title{
Patterns of Injuries in Newer Mechanisms of Pediatric Injuries (ATVs, Snowmobiles, Trampolines, Flat Screen TVs)
}

\author{
Deidre Wyrick $\cdot$ R. Todd Maxson
}

Published online: 27 May 2014

(C) Springer Science + Business Media New York 2014

\begin{abstract}
Injury is a leading cause of mortality and longterm disability for children of all ages, with intentional injuries predominating in the less than 1 year age group and unintentional injuries posing the greatest threat to life in children older than 1 year of age. Recreational vehicles are gaining in popularity and availability making their use by children a more common mode of injury. The explosion of popularity and prevalence of flat screen televisions has also changed the landscape of pediatric injuries and provided new challenges to providers of pediatric trauma care. This chapter will provide an in-depth examination of these new modes of pediatric injury and provide insight into injury control efforts that should be incorporated into every primary care provider's anticipatory teaching.
\end{abstract}

Keywords Pediatric trauma All-terrain vehicles $\cdot$ ATV . Snowmobiles · Trampolines · Flat screen televisions

\section{Introduction}

Unintentional injury poses the greatest threat to life and causes the greatest morbidity in children 1-14 years of age $[1,2]$. Injury is a leading cause of mortality and long-term disability for children of all ages, with intentional injuries

This article is part of the Topical Collection on Pediatric Trauma Surgery.

D. Wyrick $(\bowtie) \cdot$ R. T. Maxson

Department of Pediatric Surgery, Arkansas Children's Hospital, University of Arkansas for Medical Sciences, 1 Children's Way, Slot 837, Little Rock, AR 72202, USA

e-mail: dlwyrick@uams.edu

R. T. Maxson

e-mail: rtmaxson@uams.edu predominating in the less than one-year age group and unintentional injuries posing the greatest threat to life in children older than 1 year of age. Historically falls have been the leading cause of injury and motor vehicular crashes the leading cause of injury related mortality, with burns and firearm injuries having the highest lethality [1-3] (Tables 1, 2). As technology advances and the falling price of new technologies make them more widely affordable, there are new injury threats to children. Recreational vehicles are gaining in popularity, and availability making their use by children a more common mode of injury. The explosion of popularity and prevalence of flat screen televisions has also changed the landscape of pediatric injuries and provided new challenges to providers of pediatric trauma care. This chapter provides an in-depth examination of these new modes of pediatric injury, describes the injury patterns seen, discusses the treatment paradigms and most importantly, provides insight into injury control efforts that should be incorporated into every primary care provider's anticipatory teaching.

\section{ATVs}

All-terrain vehicles (ATVs) were introduced in the United States in the early 1970s and in 2008 it was estimated that there were nine million ATVs in use the US [4]. These vehicles can weigh over 500 pounds, travel up to 100 miles per hour and have 70 horsepower engines [5]. The stated intent of these vehicles was for operation in an off road environment and they were intended for single passenger use. There are specific skills of navigation, depth perception, distribution of weight and balance, and general "rules of the road" that make their operation complicated and often beyond the skill level of a pediatric patient. The successful operation of such a vehicle requires skills that are additive to, and surpass the skill 
Table 1 Unintentional fatal injuries by age, 2000-2005

\begin{tabular}{|c|c|c|c|c|}
\hline \multirow[b]{2}{*}{ Rank } & \multicolumn{4}{|c|}{ Age group in years } \\
\hline & $<1$ & $1-4$ & $5-9$ & $10-14$ \\
\hline 1 & $\begin{array}{l}\text { Suffocation } \\
66 \%\end{array}$ & $\begin{array}{l}\text { Motor } \\
\text { vehicle } \\
\text { traffic } \\
31 \%\end{array}$ & $\begin{array}{l}\text { Motor } \\
\text { vehicle } \\
\text { traffic } \\
53 \%\end{array}$ & $\begin{array}{l}\text { Motor } \\
\text { vehicle } \\
\text { traffic } \\
58 \%\end{array}$ \\
\hline 2 & $\begin{array}{l}\text { Motor } \\
\text { vehicle } \\
\text { traffic } \\
14 \%\end{array}$ & $\begin{array}{l}\text { Drowning } \\
27 \%\end{array}$ & $\begin{array}{l}\text { Other }^{\mathrm{a}} \\
15 \%\end{array}$ & $\begin{array}{l}\text { Other }^{\mathrm{a}} \\
18 \%\end{array}$ \\
\hline 3 & $\begin{array}{l}\text { Drowning } \\
7 \%\end{array}$ & $\begin{array}{l}\text { Other }{ }^{\mathrm{a}} \\
15 \%\end{array}$ & $\begin{array}{l}\text { Fire/burn } \\
13 \%\end{array}$ & $\begin{array}{l}\text { Drowning } \\
10 \%\end{array}$ \\
\hline 4 & $\begin{array}{l}\text { Other }{ }^{\mathrm{a}} \\
6 \%\end{array}$ & $\begin{array}{l}\text { Fire/burn } \\
14 \%\end{array}$ & $\begin{array}{l}\text { Drowning } \\
13 \%\end{array}$ & $\begin{array}{l}\text { Fire/burn } \\
6 \%\end{array}$ \\
\hline 5 & $\begin{array}{l}\text { Fire/burn } \\
4 \%\end{array}$ & $\begin{array}{l}\text { Suffocation } \\
8 \%\end{array}$ & $\begin{array}{l}\text { Suffocation } \\
4 \%\end{array}$ & $\begin{array}{l}\text { Suffocation } \\
4 \%\end{array}$ \\
\hline
\end{tabular}

* Includes ATV accidents

Table 2 Unintentional nonfatal injuries by age, 2001-2006

\begin{tabular}{lllll}
\hline \multirow{4}{*}{ Rank } & \multicolumn{4}{l}{ Age group in years } \\
\cline { 2 - 5 } & $<1$ & $1-4$ & $5-9$ & $10-14$ \\
\hline 1 & Falls & Falls & Falls & Falls \\
& $52 \%$ & $43 \%$ & $37 \%$ & $28 \%$ \\
2 & Struck by or & Struck by or & Struck by or & Struck by or \\
& against & against & against & against object \\
& object & object & object & $25 \%$ \\
& $14 \%$ & $19 \%$ & $23 \%$ & \\
3 & Bite/sting & Bite/sting & Bite/sting & Overexertion \\
& $6 \%$ & $9 \%$ & $8 \%$ & $12 \%$ \\
& Fire/burn & Foreign & Cut/pierce & Cut/PIERCE \\
& $5 \%$ & body & $7 \%$ & $7 \%$ \\
& & $6 \%$ & & \\
5 & Foreign & Cut/pierce & Bicycle & Bicycle \\
& body & $4 \%$ & $6 \%$ & $6 \%$ \\
& $4 \%$ & & & \\
\hline
\end{tabular}

necessary to operate a bicycle and many other motorized vehicles. The paradox is that many of the injuries seen are in children who do not yet possess competency in the operation of a bicycle, let alone a motorized vehicle.

This size and speed poses a unique risk to children who operate these vehicles because they often do not have the size, weight, manual dexterity or cognitive ability to properly handle them [6]. In fact, children younger than 16 years only make up $14 \%$ of ATV riders nationally but account for $37 \%$ of ATV-related injuries and $28 \%$ of ATV-related fatalities [7]. This discrepancy in ridership to injury and mortality, when compared to adult riders emphasizes the relative risk to young riders. Due to increased numbers of ATV injuries in the 1980s the United States Consumer Product Safety Commission filed a lawsuit against ATV manufacturers that resulted in the "consent decrees". These consent decrees set forth rules for manufacturers of ATVs and included: (1) provisions to terminate the production and retail of the unstable three wheel ATV for the "safer" four wheel version, (2) recommend ATVs not carry passengers, (3) offer free safety courses to drivers, (4) recommend age to engine size compatibility, (5) recommend ATVs not be used for roadway travel, (6) require children younger than 16 years have adult supervision and (7) require helmet use at all times. These decrees were mandatory, went into effect in 1988 and lasted for 10 years, during which time failure to comply with the consent decrees could result in loss of the franchise and/or fines [8]. After the 10-year period manufacturers agreed to voluntarily follow "ATV Action Plans" which were less restrictive than the consent decrees [9]. Despite this good faith effort on behalf of the Consumer Product Safety Commission, failure to further regulate the use of these vehicles by children has contributed to a steady increase in the numbers of injuries, fatalities and children with permanent disability [10-12]. In 2007, Helmkamp et al. [13] estimated that the annual cost of caring for ATV related injuries exceeded $\$ 750$ million dollars.

Many factors contribute to injuries related to ATVs. Campbell et al., conducted a survey of children to assess attitudes toward ATV use. They found that not only does riding begin at a young age (9.2+- 3.2 years) but $60 \%$ admit to riding without adult supervision. Furthermore, very few children reported using appropriately sized engines, almost half reported riding without helmets and $70 \%$ rode with passengers. Finally, they found that more than $95 \%$ riders did not receive any formal safety instruction on appropriate use of ATVs [14]. The lack of safety training, helmet use and riding inappropriately sized vehicles has been corroborated by several other studies [15-19]. Additionally, legislation on appropriate use and sale of ATVs is variable from state and enforcement is difficult. In 2012, only 31 states had a helmet requirement and only 33 states had minimum age requirements for operating ATVs [20]. Many of those states that have language that limits ridership by age have waivers for operation on private land, rendering the statutes ineffective.

ATV accidents are frequently high-energy injuries and riders have little protection which results in frequent hospitalization when injury does occur. Shults et al., found that, when compared to all emergency department visits related to injury, ATV injuries were seven times more likely to be hospitalized. When compared to motor vehicle collisions, ATV injuries were twice as likely to require hospitalization [21•]. In accordance with trends in other mechanisms of injury, boys are more often injured and 


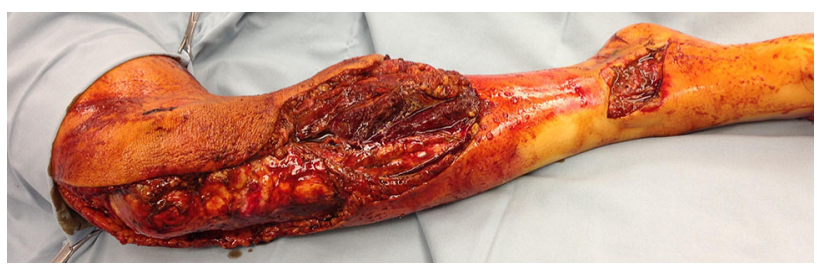

Fig. 1 Right lower extremity soft tissue injury

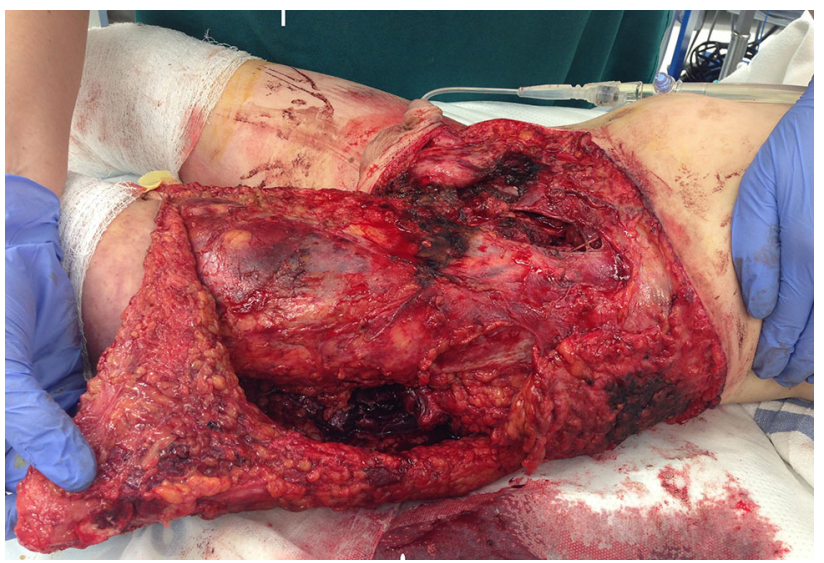

Fig. 2 Left lateral thigh/hip degloving injury

more often hospitalized when compared to girls $[11,15-$ $18,21 \bullet, 10,22,23]$. Head injuries are the most commonly documented injuries $[10,16,21 \bullet, 23,24]$. Orthopedic fractures and spine injuries are also common injury patterns in ATV accidents [21 $, 22,24]$. When spine fractures are found, $45 \%$ are multiple and in children $<16$ years old lumbar spine fracture predominate [22]. Multi-system injury is reported in 40-55\% of injuries and evaluation for a second injury should be undertaken in this patient population $[10,22,25]$. It seems that in older riders drivers are more commonly injured but in younger riders passengers are more commonly injured $[17,18]$. The most common mechanism of injury related to ATV accidents was ejection from the vehicle, followed by crush injury when the vehicle rolls or flips [16, 18, 25].

Because ATV riders are relatively unprotected when accidents do occur they can have extensive soft tissue injuries (Figs. 1, 2, 3). These injuries are often contaminated and require thorough irrigation and multiple debridements prior to extensive reconstruction. When associated with open fractures a multidisciplinary approach must be taken to achieve adequate recovery.

Due to the threat of injury to children who ride ATVs, the American Academy of Pediatrics, American College of Surgeons, American Pediatric Surgical Association, and Canadian Association of Pediatric Surgeons have put forth guidelines for the safe use these vehicles. Although there are minor variations between each set of guidelines, all

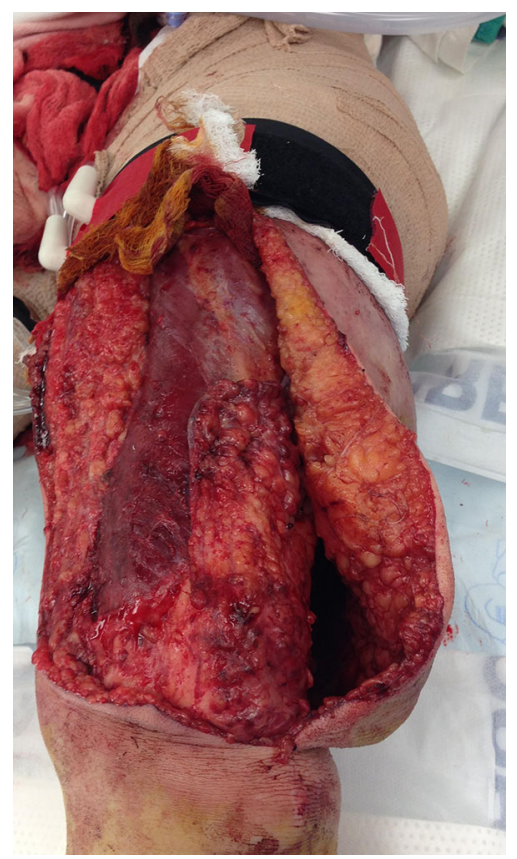

Fig. 3 Left anterior thigh soft tissue injury

agree that children $<16$ years of age should not operate ATVs. At a minimum, those $>16$ should have an automobile driver's license, and preferably some additional certification for ATV use. ATVs are designed for a single rider, and no passenger should ever be on board. Finally, government approved helmets should be worn while operating these vehicles although the injury patterns are such that use of helmets will not routinely prevent death or significant disability. [13, 26-29]. Anticipatory teaching should stress that ATVs are not toys, but are motorized vehicles that children do not have the strength, cognition or motor skills to operate safely.

\section{Snowmobiles}

Similarly to all-terrain vehicles, snowmobiles are large vehicles, weighing up to 600 pounds, and can travel up to 110 miles per hour [30]. In 2013, 48,536 snowmobiles were sold in the United States and there were 1.4 million registered snowmobiles [31, 32]. There are currently over 225,000 miles of dedicated snowmobile trails in North America [33] and this does not include the numerous trails on private property.

As with ATVs, there are several factors contributing to the injury patterns seen in children who drive and ride on snowmobiles. The first being that children often do not have the strength, manual dexterity or cognition needed to operate large motorized vehicles [34]. Legislation related to operation of snowmobiles is less restrictive than for 
other types of motor vehicles [34]. The Snowmobiling Hazards Committee on Injury and Poison Prevention examined legislation in the 18 states with the highest snowmobile ownership and found that $61 \%$ had no helmet requirements. Of the states that did have helmet legislation the laws only applied to those $<18$ years old and do not comment on passengers. Many states do not have age restrictions and for those that do, there is great variability in minimum age requirements. In some states, children as young as 8 years old can operate snowmobiles provided they have attended a state course. In a similar fashion, children as young as 14 years old can act as "adult supervision" if they have attended safety classes. It is important to note that state laws are applicable only on public land and do not govern operation on private property [34].

As with other reported motorized vehicles, males were more frequently injured than females. Orthopedic and head injuries are the two most common injury patterns seen in snowmobile accidents. Although, not the main cause of injury, head injuries account for the majority of fatalities. The most common causes of injury included collision with a stationary object, rollover, and fall from the vehicle. The mechanism that was attributed to the highest mortality was collision with a stationary object $[30,35,36]$. An interesting mechanism of injury seen is related to children being towed behind the snowmobile $[34,35]$. Potentially unique injury patterns of near drowning and frostbite are rarely reported in the adult or pediatric literature [34]. In 2001, Skokan et al., reported on hospital charges for taking care of snowmobile injuries in the state of Utah. Over the 2 year study period the median cumulative charge in Utah was $\$ 266,283$ for emergency department treatment and $\$ 1.3$ million for inpatient treatment of snowmobile injuries [37].

In 2000 the American Academy of Pediatrics published guidelines concerning the safe operation of snowmobiles. They state the following: (1) children younger than 16 years should not operate snowmobiles, (2) children younger than 6 years do not have the strength or stamina to be transported safely as passengers on snowmobiles, (3) advertisements that promote snowmobiling should not be directed toward young adolescents, and advertisements should not depict young adolescents driving snowmobiles, (4) for drivers $>16$ years old graduated licensing is recommended, (5) snowmobilers should travel at safe speeds, (6) snowmobilers should avoid the use alcohol or other drugs before or during the operation of a snowmobile, (7) all drivers and passengers should wear helmets, (8) snowmobilers should avoid snowmobiling on ice if they are uncertain about its thickness or condition, (9) snowmobilers should not carry more than one passenger, and (10) use of a saucer, tube, tire, sled, or skis to pull someone behind a snowmobile is not recommended [34].
Similarly to ATVs, primary care physicians should stress that snowmobiles are motorized vehicles, not toys, and similar care should be taken during the operation of these vehicles; including limiting use to those $>16$ years old. It should be noted that young children do not have the strength to safely ride as passengers and that a passenger should never be pulled behind a snowmobile.

\section{Trampolines}

The trampoline was first introduced to the United States by acrobat George Nissen in 1936 and was used to train fighter pilots during World War II [38]. The trampoline gained popularity as a recreational device in the 1950s and 1960s [38], which not surprisingly corresponded to the first documented reports of injuries due to trampoline use [39, 40]. Between the years 1990-1995 there were approximately 250,000 trampoline injuries in the United States [38].

One of the most consistently documented contributors to injury was having more than one person on the trampoline at a time [41-46, 47•]. When an injury does occur with multiple jumpers, the lightest jumper, often the child, is the most frequently injured person $[41,42]$. The industry, and probably intuition suggest that safety devices such as mats and nets as well as strict adult supervision make this activity less risky for children. Interestingly, approximately $50 \%$ of injuries occurred with direct adult supervision [41, 42]. Additionally, 44-56 \% of injuries occurred with safety nets and/or mats in place $[43,46]$.

Although the numbers vary slightly between studies, the injuries are essentially evenly split between males and females [38, 43, 44]. Reported injury patterns remain stable across all studies with extremity injuries occurring as the dominant injury type [38, 43-46, 47•]. Gary Smith and colleagues noted that $64 \%$ of upper extremity injuries were fracture/dislocation injuries and $69 \%$ of lower extremity injuries were soft tissue injuries [38]. The majority of these injuries were seen and then discharged from the emergency department, with 3-20\% of children requiring admission for their injury. The most common reason for admission was fracture/dislocation repair under anesthesia [38, 41, 45, 46]. It is important to note that while cervical spine injuries account for a small number of injuries, $10-17 \%$, spine injuries are the major cause of morbidity and mortality in trampoline injuries [44, 47•, 48].

The role of the American Academy of Pediatrics Council on Sports Medicine and Fitness is to support and encourage safe physical activity in the pediatric population and to provide pediatric providers with guidance on appropriate participation of their patients. In this role, they have published guidelines and recommendations for many sports and physical activities. The council recently released 
guidelines on the safe and appropriate use of trampolines. In summary, they recommend that pediatricians should counsel their patients and families against recreational trampoline use. For those families that insist on using trampolines, they recommend the following: (1) insuring homeowners insurance policies cover trampoline related claims, (2) trampoline use should be restricted to a single jumper at any given time, (3) trampolines should have adequate padding in place, (4) trampolines should be set at ground level in an area clear of any surround hazards, 5) frequent inspection and appropriate replacement of protective padding, net enclosure, and any other damaged parts should occur, (6) trampolines should be discarded if replacement parts are unavailable and the product is worn or damaged, (7) somersaults and flips should not be performed in the recreational setting, (8) active supervision by adults familiar with the above recommendations should occur at all times, and (9) parents should confirm these guidelines are in place anytime their child is likely to use a trampoline [47•].

\section{Flat Screen Televisions}

Many studies have documented the injury patterns seen with large cathode ray televisions, which usually were pulled over onto a child, often toddlers cruising, leading to significant head injury [49]. Data is lacking on injuries related to flat screen televisions. Many studies within the last several years report a combination of cathode ray and flat screen television data making conclusions in regards to flat screen televisions difficult to interpret. Of particular importance are "tip-over" injuries. In 2007 the Consumer Product Safety Commission released the top five hidden hazards of home and tip-over injuries, such as large television screens, which were ranked as the third leading cause of morbidity and mortality [50] (Table 3). These injuries occur when the large flat screen televisions are mounted on a stand on a piece of furniture or hung on the wall within grasp of a child.

It appears that boys are more commonly injured in television accidents when compared to girls [51-53]. Multiple studies agree that the vast majority of these injuries occur in the home [51-54] and that most injuries are unwitnessed events [51, 53]. The most commonly reportedly injured area of the body was the head [51-54]. When compared to injuries to the body, injuries to the head often resulted in the more severe injuries and required more intensive care with longer hospital stays [52]. There is speculation that lighter weights coupled with a less bulky design may make flat screen televisions more easily tipped than cathode ray televisions and may be contributing to the observed increase in the rate of injuries associated with
Table 3 Top 5 hidden hazards of the home

\begin{tabular}{ll}
\hline 1 & Magnets \\
2 & Recalled products \\
3 & Tip-overs \\
4 & Window and window coverings \\
5 & Pool and spa drains \\
\hline
\end{tabular}

falling television [51, 53]; however, there is little data to support or refute this claim.

\section{Conclusion}

Injury control and prevention is a dynamic science and must adapt to changing threats posed to children. While we welcome change that brings new products to market, these technological advances and the introduction of readily available recreational vehicles and equipment must be examined for the potential threat that they create for naturally curious children who may be exposed. This chapter provides insight into a few of these newer threats and hopefully provides the pediatric practitioner information that is useful in anticipatory discussions with families and caregivers.

\section{Compliance with Ethics Guidelines}

Conflict of Interest R. Todd Maxson has served as a consultant for the American College of Surgeons and the Arkansas Department of Health. Deidre Wyrick declares that she has no conflict of interest.

Human and Animal Rights and Informed Consent This article does not contain any studies with human or animal subjects performed by any of the authors.

\section{References}

Papers of particular interest, published recently, have been highlighted as:

- Of importance

1. Cooper A. Early assessment and management of trauma. In: Holcomb III G, editor. Ashcraft's pediatric surgery. 5th ed. Philadelphia: Elsevier Inc.; 2010. p. 167-81.

2. CDC Childhood Injury Report. Available at: http://www.cdc.gov/ SafeChild/images/CDC-ChildhoodInjury.pdf. Accessed 4 April 2014.

3. Lukish JR, Eichelberger MR. Infants and children as accident victims and their emergency management. In: Coran A, editor. Pediatric Surgery. 7th ed. Philadelphia: Elsevier Inc.; 2012. p. 261-70.

4. United States Consumer Product Safety Commission. 2008 Annual Report of ATV Deaths and Injuries. Available at: http:// 
www.cpsc.gov/LIBRARY/FOIA/FOIA10/os/atv2008.pdf. Accessed 11 Nov 2013.

5. United States Consumer Product Safety Commission. 2009 Annual Report of ATV Deaths and Injuries. Available at: http:// www.cpsc.gov/library/foia/foia11/os/atv2009.pdf. Accessed 11 Nov 2013.

6. Dolan MA, Knapp JF, Andres J. Three-wheel and four-wheel allterrain vehicle injuries in children. Pediatrics. 1989;84:694-8.

7. Consumer Federation of America. All-terrain vehicle (ATV) safety crisis: America's children at risk. Washington, DC: Consumer Federation of America; 2002.

8. U.S. District Court for the District of Columbia. United States of America versus American Honda Motor Co., Inc., et al: Final consent decree-Civil action number 87-3525; 14 Mar 1988.

9. Committee American Pediatric Surgical Association Trauma. American pediatric surgical association trauma committee position statement on the use of all-terrain vehicles by children and youth. J Pediatr Surg. 2009;44:1638-9.

10. Humphries RL, Stone CL, Stapczynski JS, et al. An assessment of pediatric all-terrain vehicle injuries. Pediatr Emerg Care. 2006;22:491-4.

11. Blecker N, Rhee P, Judkins DG, et al. Pediatric all-terrain vehicle trauma the epidemic continues unabated. Pediatr Emerg Care. 2012;28:443-7.

12. Bowman SM, Aitken ME. Still unsafe, still in use: ongoing epidemic of all-terrain vehicle injury hospitalization among children. J Trauma. 2010;69:1344-9.

13. Helmkamp J, Lawrence BA. The economic burden of all-terrain vehicle-related pediatric deaths in the United States. Pediatrics. 2007;119:223-5.

14. Campbell BT, Kelliher KM, Borrup K, et al. All-terrain vehicle riding among youth: how do they fair? J Pediatr Surg. 2012;45: 925-9.

15. Bowman SM, Aitken ME, Helmkamp JC, et al. Impact of helmets on injuries to riders of all-terrain vehicles. Inj Prev. 2009;15:3-7.

16. McBride AS, Cline DM, Neiberg RH, et al. Pediatric all-terrain vehicle injuries: does legislation make a dent? Pediatr Emerg Care. 2011;27:97-101.

17. Shah SR, McKenna C, Miller M, et al. Safety factors related to all-terrain vehicle injuries in children. J Trauma Acute Care Surg. 2012;73:s273-6.

18. Unni P, Morrow SE, Shultz BL. Analysis of pediatric all-terrain vehicle trauma data in Middle Tennessee: implications for injury prevention. J Trauma Acute Care Surg. 2012;73:S277-80.

19. Rodgers GB. The characteristics and use patterns of all-terrain vehicle drivers in the United States. Accid Anal Prev. 1999;31: 409-19.

20. Specialty Vehicle Institute of America. State all-terrain vehicle requirements. Irvine, CA: Government Relations Office, Specialty Vehicle Institute of America; February 2012. Available at: www.svia.org/Downloads/SVIASummary-Chart-February-2012. pdf. Accessed 11 Nov 2013.

21. - Shults RA, West BA, Rudd RA, et al. All-terrain vehicle-related nonfatal injuries among young riders in the United States. Pediatrics 2013;132:282-289. An examination of nonfatal injuries over the last several years. Examines possible reasons that ATV injuries may be decreasing.

22. Sawyer JR, Beebe M, Creek AT, et al. Age-related patterns of spine injury in children involved in all-terrain vehicle accidents. J Pediatr Orthop. 2012;32:435-9.

23. Keenan HT, Bratton SL. All-terrain vehicle legislation for children: a comparison of a state with and a state without a helmet law. Pediatrics. 2004;113:e330-4.

24. Shah CC, Ramakrishnaiah RH, Bhutta ST, et al. Imaging findings in 512 children following all-terrain vehicle injuries. Pediatr Radiol. 2009;39:677-84.
25. Hale N, Brown A. Mechanistic relationship of all-terrain vehicles and pediatric renal trauma. Urology. 2013;81:160-2.

26. American Academy of Pediatrics, Committee on Injury and Poison Prevention. All-terrain vehicle injury prevention: two-, three-, and four-wheeled unlicensed motor vehicles. Pediatrics. 2000;105:1352-4.

27. American College of Surgeons, Committee on Trauma, SubCommittee on Injury Prevention and Control. Statement on allterrain vehicle injuries. Bull Am Coll Surg. 2009;94:37-8.

28. Canadian Association of Paediatric Surgeons, Trauma Committee. Position statement on the use of all-terrain vehicles by children and youth. J Pediatr Surg. 2008;43:938-9.

29. Gittelman AM, Pomerantz WJ, Groner JI, et al. Pediatric allterrain vehicle-related injuries in Ohio from 1995 to 2001: using the injury severity score to determine whether helmets are a solution. Pediatrics. 2006;117:2190-5.

30. DeCou JM, Fagerman LE, Ropele D, et al. Snowmobile injuries and fatalities in children. J Pediatr Surg. 2003;38:784-7.

31. International Snowmobile Manufacturers Association. Snowmobile Statistics. Available at www.snowmobile.org/stats registrations_us.asp. Accessed 2 Dec 2013.

32. International Snowmobile Manufacturers Association. Snowmobile Statistics. Available at www.snowmobile.org/stats_units_us. asp. Accessed 2 Dec 2013.

33. International Snowmobile Manufacturers Association. Snowmobile Statistics. Available at www.snowmobile.org/pr_snowfacts. asp. Accessed 2 Dec 2013.

34. American Academy of Pediatrics, Committee on Injury and Poison Prevention. Snowmobiling hazards. Pediatrics. 2000;106: 1142-4.

35. Rice MR, Alvanos L, Kenney B. Snowmobile injuries and deaths in children: a review of national injury data and state legislation. Pediatrics. 2000;105:615-9.

36. Nayci A, Stavlo PL, Sarroug AE, et al. Snowmobile injuries in children and adolescents. Mayo Clin Proc. 2006;81:39-44.

37. Skokan EG, Oslon LM, Cook LJ, et al. Snowmobile injuries in Utah. Acad Emerg Med. 2001;8:1173-7.

38. Smith GA. Injuries to children in the United States related to trampolines, 1990-1995: a national epidemic. Pediatrics. 1998; 101:406-12.

39. Zimmerman HM. Accident experience with trampolines. Res Q. 1956;27:452-5.

40. Ellis WG, Green D, Holzaepfel NR, et al. The trampoline and serious neurological injuries. A report of five cases. JAMA. 1960;174:1673-6.

41. Hurson C, Browne K, Callender O, et al. Pediatric trampoline injuries. J Pediatr Orthop. 2007;27:729-32.

42. Smith GA, Shileds BJ. Trampoline-related injuries to children. Arch Pediatr Adolesc Med. 1998;152:694-9.

43. Klimek P, Juen D, Stranzinger E, et al. Trampoline related injuries in children: risk factors and radiographic findings. World J Pediatr. 2013;9:169-74.

44. Furnival RA, Street KA, Schunk JE, et al. Too many pediatric trampoline injuries. Pediatrics. 1999;103:e57.

45. Wootton M, Harris D. Trampolining injuries presenting to a children's emergency department. Emerg Med J. 2009;26: 728-31.

46. Eberl R, Schalamon J, Singer G, et al. Trampoline-related injuries in childhood. Eur J Pediatr. 2009;168:1171-4.

47. Council on Sports Medicine and Fitness, American Academy of Pediatrics. Trampoline safety in childhood and adolescence. Pediatrics 2012;130:774-779. The current recommendations from the AAP on trampoline safety.

48. Leonard H, Joffe AR. Children presenting to a Canadian hospital with trampoline-related cervical spine injuries. Paidiatr Child Health. 2009;14:84-8. 
49. Ota FS, Maxson RT, Okada PJ. Childhood injuries caused by falling televisions. Acad Emerg Med. 2006;13:700-3.

50. Consumer Reports. Babies, children and TV tip over accidents, 2007. http://www.consumerreports.org/cro/news/2007/08/ the-cpsc-releases-the-top-five-hidden-home-hazards/index.htm. Accessed 2 Dec 2013.

51. Murray KJ, Griffin R, Rue LW, et al. Recent trends in television tip over-related injuries among children aged 0-9 years. Inj Prev. 2009; 15:240-3.
52. Millsa J, Grushkab J, Butterworth S. Television-related injuries in children-the British Columbia experience. J Pediatr Surg. 2012;47:991-5.

53. DeRoo AC, Chounthirath T, Smith GA. Television-related injuries to children in the United States, 1990-2011. Pediatrics. 2013;132:267-74.

54. Rutkoski JD, Sippey M, Gaines BA. Traumatic television tipovers in the pediatric population. J Surg Res. 2011;166:199-204. 